\title{
Kuşaklararası Çatışma Bağlamında Gençlerin Yaşlılara Eleştirel Bakışı: Bir Örneklem, Sorunlar ve Çözüm Önerileri
}

\author{
DOI: $10.26466 /$ opus.677142
}

\author{
Tümer Ulus* \\ *Dr.Öğr.Üyesi, İstanbul Üniversitesi Cerrahpaşa Sağlık Bilimleri Fakültesi Gerontoloji Bölümü \\ E-Posta: tumerulus@gmail.com ORCID: 0000-0001-7482-0974 \\ Öz
}

Tarihin başlangıcından bu yana gençlerle yaşlılar arasında iletişim sorunları ve bir kuşak çatışması meselesi olduğu bir gerçektir. Bu çatışmalar, sadece kişisel değgil sosyal bir sorun olarak da varlı̆̆ın sürdürmektedir; genç ve yaşl bireylerin kişisel hayatların olduğu kadar onları çevreleyen toplumsal işleyişi de verimsizleştirmektedir. Bu durum, birbirinden aslında çok yararlanabilecek ve yararlanması gereken bu iki grubu birbirinden uzaklaştırmakta ve birbirine yabancllaştırmaktadır. Bu çerçevede, bu makalenin amacı, taraflardan biri olan gençlerin yaşlılara nasıl baktığını, örnek bir grup üzerinde çalışarak incelemektir. Gençlerin yaşllları nasıl değerlendirdiğ̈i, hangi açılardan eleştirdiği mercek altına alınmakta, tartışılmakta ve saptanan sorunlara çözüm önerileri sunulmaktadır. Bu amaçla, özellikle Gerontoloji (Yaşlanma ve Yaşlılık Bilimi), Sosyal Hizmet ve FTR (Fizyoterapi ve Rehabilitasyon) Bölümlerinde okuyan bir grup üniversite öğrencisi ile çalışılmıştır. Örneklem için seçilen bu öğrenciler, almakta oldukları eğitim gereği, yaşlanma ve yaşlılıkla ilgili zorunlu velya seçmeli derslere katılmış olan ve konuyla ilgili bilgiye sahip olması beklenen öğrencilerdir. Bu gençlere, yapılandırılmış soru-cevap tekniği ile yaşlılarla ilgili eleştirileri sorulmuştur. Makalede, öncelikle öğrencilere sorulan bu sorunun ne olduğu ile ilgili bilgi verilmiş ve sonra da gençlerin verdikleri cevaplarla ilgili ayrıntılar sunulmuştur. Ardından da alınan cevaplar doğrultusunda durum değerlendirmesi yapılmış ve sorunlar saptanmıştır. Sonuç olarak da, saptanan sorunların çözümü için tartışma ve öneriler sunulmuştur

Anahtar Kelime- Yaşlılar, gençler, kuşaklararası çatışma, ayrımcılık, yaş ayrımcılı̆̆ı ler: 


\title{
The Critical Approach of Young People to the Elderly within the Context of Intergenerational Conflict: A Sample Group, Problems and Suggestions for Solutions
}

\begin{abstract}
It is a fact that since the beginning of history, there have been communicational problems and intergenerational conflict between young and elderly people. This has caused both personal and social problems, weakening the potential productivity not only in the personal lives of young and elderly individuals but also in the workings of society surrounding them. It has created distance and alieanation between these two groups, who can and should benefit from one another. This article, by working on a sample group, aims to analyse how young people see elderly people. It tries to understand from which aspects young people criticize elderly people, to discuss the problems and to suggest solutions. The members of the sample group were especially selected from among the university students studying at the departments of Gerontology, Social Work, and Physical Therapy and Rehabilitation. Thus, they had already taken compulsory and/or elective courses on aging and old age and were expected to have knowledge on the subject. Through the question-answer method, they were asked questions about their negative views on elderly people. The article first presents data on the question asked and the answers received. Then, it discusses the observed problems and offers suggestions for the solution.
\end{abstract}

Keywords: Elderly people, young people, intergenerational conflict, discrimination, agism 


\section{Giriş}

"Bilmek yetmez, bilgimizi kullanmahyız da; istemek yetmez, yapmahyız da." Johann Wolfgang von Goethe

Toplumun her anlamda sağlıklı ve verimli işleyebilmesi için yaşlı bireylerin ve gençlerin birbirini tanıması, anlaması ve doğru bir iletişim içinde olması büyük önem taşımaktadır. Bununla birlikte, aslında birbirinden çok yararlanabilecek olan ve yararlanması gereken bu iki grup arasındaki iletişim sorunları ve kuşak çatışmaları tarih boyunca pek çok farklı kültür ve coğrafyada önemli bir kişisel ve toplumsal sorun olmuştur. Konunun çok eski zamanlardan bu yana varlığını sürdürdügünü ve yaygınlığını vurgulayan Lamia Levent'in de belirttiği gibi, "Eski Misır papirüslerinde ve Hitit tabletlerinde gençler ve yetişkinler arasında yaşanan kuşak çatışmasını konu edinen bölümlerin yer alması; hangi çağda olursak olalım, gençleri anlama mevzuu üzerine daha fazla çaba göstermemiz gerektiğinin önemli bir işareti sayılmalı." (Levent, 2015, s.5)

Yaşlı ve genç kuşaklar arasındaki sorunların ve birbirini tanıma ve anlama meselesinin başlangıç noktasında, tarafların birbirlerini nasıl gördükleri konusu ele alınmalıdır. Bu makale, tarafların birbirlerini nasıl gördükleri ve hangi açılardan eleştirdikleri konusu bağlamında, özellikle "gençlerin yaşlıları nasıl gördükleri" meselesini incelemektedir. Çalışmanın özel olarak odaklandığı nokta ise, "gençlerin yaşlıları hangi açılardan eleştirdikleri" konusudur. Makale, konunun bu boyutunu anlamayı ve tartışmayı amaçlamaktadır. (Bunun tersi, yani "yaşlıların gençleri nasıl gördükleri ve hangi aç1lardan eleştirdikleri" konusu ise, yine bu makalenin yazarı tarafından yayıma hazırlanmakta olan ikinci bir makalede ele alınmaktadır.)

Gençlerin, "yaş almanın, yaşlanmanın ve yaşlılığın" ne anlama geldiğini anlaması ve bu konuda farkındalık kazanması, genel anlamda önemli bir konudur. "Gençlerin Yaşlı Bireylere Karşı Tutumu" başlıklı makalelerinde Ucun, Mersin ve Öksüz'ün de belirttiği gibi, “Bugünün öğrencisi, yarının uygulamaların sorumlusu ve uygulayıcıları olan üniversite öğrencilerinin yaşlı bireylere karşı tutumlarının araştırılması eksikleri gidermek açısından önemli olacaktır" (Ucun, Mersin ve Öksüz, 2015, s.1147). Daha özel anlamda ise, "yaşlılık ve yaşlanma" konularında meslekî faaliyet gösterecek olan ve hali hazırda bu yönde bir yüksek öğretim kurumunda eğitim almakta olan 
genç bireylerin bu konudaki bilgi ve farkındalık düzeyleri çok büyük önem taşımaktadır. Bu genç grubunun zihninde "yaşlılığın”, "yaş almanın”, , yaşlanmanın" ve "yaşlıların" ne anlama geldiğinin net bir şekilde anlaşılması önemlidir.

Bu makalede, bu yönde bilgi sağlamaya yönelik olarak, bir örneklem grubu ile, bu makalenin yazarı tarafından yapılan uygulamalı bir çalışmanın ayrıntıları ele alınacak. "Gençlerin gözünde yaşlılığın ne olduğu”, " gençlerin yaşlıları nasıl gördüğü" ve özellikle de "gençlerin yaşlıları hangi açılardan eleştirdikleri" ile ilgili ulaşılan veriler sunulacak, tartışılacak ve değerlendirilecektir.

\section{Amaç}

Bu çalışmanın amacl, gençler ve yaşlılar arasında yaşanmakta olan kuşak çatışması sorununun anlaşılmasına ve çözümüne katkı sağlamaktır. Bu doğrultuda, önce kuşak çatışması sorununun bir boyutu olarak, genç bireylerin yaşlı algısı anlaşılmaya çalışılmıştır. Genç bireylerin yaşıı algısına ulaşmak üzere, konuyla ilgili olarak doğrudan doğruya gençlerin kendi duygu ve düşüncelerini ifade etmelerine fırsat tanınmıştır. Daha sonra ise, ulaşılan verilerin ayrıntılı analizi ile, çatışmaya yol açan faktörler ve bu faktörlerin ortaya çıkış sebepleri tanımlanmaya çalışılmıştır. Böylelikle, sorunların giderilmesine yönelik tartışma ve öneriler ortaya koyularak, kuşak çatışması meselesinin çözümüne katkı sağlanmaya çalışılmıştır.

\section{Yöntem}

Bu çalışma, lise mezunu, yaşları 17-22 arasında değişen, (Kars'tan Edirne'ye, Muğla'dan Trabzon'a) ülkenin pek çok farklı bölgesinden yüksek öğrenim amacıyla İstanbul'a gelmiş olan ve hali hazırda bir devlet üniversitesi ve bir vakıf üniversitesinde üç farklı bölümde okuyan bir grup öğrenci ile yapılmıştır. Bu öğrencilerle, sınıf ortamında, iki soru yazdırılması ve bu sorulara yine yazılı olarak cevap vermelerinin istenmesi şeklinde bir soru-cevap uygulaması yapılmıştır. Öğrencilerin okudukları söz konusu bu bölümler, "Gerontoloji", "Sosyal Hizmet" ve "Fizyoterapi ve Rehabilitasyon" bölümleridir. Seçilen bu ögrrenciler, eğitimlerinin birinci, ikinci, dördüncü ve sekizinci yarıyıl- 
larında okuyan öğrencilerdir ve zorunlu ya da seçmeli olarak temel "yaşlanma ve yaşlılık bilimi" konulu çeşitli dersler almışlardır ya da almaktadırlar. Öğrenciler, bu makalenin yazarının verdiği "Sosyolojik Yaşlanma", "Psikolojik Yaşlanma"," Biyolojik Yaşlanma”, "Yaşlılarda Boş Zaman Değerlendirmesi", "Yaşlı Bakımı" ve "Sağlıklı Yaşlanma”, "Antropoloji”, “Kuşaklararası İlişkiler" "Yaşlılıkta Eğitim", "Yaşlı Bakım Modelleri" başlıklı dersleri almışlardır ya da almaktadırlar. Dolayısıyla, bu öğrenciler, bu dersler kapsamında "yaşlılık nedir" ve "yaşlanma nedir" temel konularında bilgilendirilmiş olan gençlerdir.

Veri toplama aracı olarak, öğrencilerin yukarıda sözü edilen yapılandırılmış sorulara verdikleri cevaplar kullanılmıştır. Öncelikle, bu öğrencilere soru-cevap uygulaması yapılmadan önce, öğrencilerin gerçek duygu ve düşüncelerini ifade edebilmelerine imkan sağlanmasına büyük önem verilmiştir. Öğrencilerin, kendilerini herhangi bir sosyal-kültürel baskı altında hissetmemesi ya da kendilerine oto-sansür uygulama zorunluğu duymaması için çaba sarf edilmiştir. Bu nedenle, öğrencilerden ad, soyadı ya da kimlik bilgileri istenmemiştir. Kendilerine o sırada dağıtılan boş kâğıtlara, sadece (kadın/erkek şeklinde) "cinsiyetlerini" ve de "yaşlarını" yazmaları istenmiştir. Sonrasında da, "gençlerin yaşlılarla ilgili olumsuz düşüncelerini ve eleştirdikleri yönleri" ifade etmeleri istenmiştir.

Yukarıda belirtildiği gibi, bu öğrenciler, "yaşlılık" ve "yaşlanma" konularında bilgilenmelerine imkân tanıyan dersler almışlardır, fakat bu çalışma kapsamında kendilerine sorulan bu soru, daha önce derslerde hiç gündeme getirilmemiş bir sorudur. Öğrencilere, hiçbir ön hazırlık yapmalarına ya da konu ile ilgili daha önceden düşünüp fikir ya da yorum geliştirmelerine firsat vermeden, sade ve net bir soru sorulmuştur. Öğrencilere sorulan soru şudur: "Yaşlılarda en beğenmediğiniz, sevmediğiniz, şikâyetçi olduğunuz iki özelliği, çok kısaca, içinizden geldiği gibi, iki madde halinde yazınız". Soru ve cevap aşaması sadece 5 dakika olarak sinırlandırılmıştır. Bu soru-cevap çalışmasına, yukarıda belirtilen iki bölümden toplam 323 öğrenci katılmış ve soruları cevaplamıştır. Öğrencilerin 251'i kadın, 72'si ise erkektir. Öğrencilerin \% 99'u, kendilerine sorulan soruya, istenilen şekilde, iki madde halinde cevap vermiştir. Öğrencilerden alınan ve aşağıda ayrıntıyla değerlendirilecek olan toplam 642 cevap ortaya çıkmıştır. 
Veri analizi aşamasında, öğrencilerin verdikleri cevaplar yaşlılara yaklaşımları açısından üç ana kategoriye ayrılmıştır; sonrasında ise incelemeler ve tartışmalar bu çerçeve üzerine inşa edilmiştir.

\section{Bulgular}

Yukarıda belirtilen 642 cevap tarandığında, bu araştırmanın ana problem olan kuşaklararası çatışma ve alt problem olarak ele alınan gençlerin yaşlılara yaklaşımı konularında elde edilen bulguların, ana hatlarıyla üç grup altında sınıflandırılabileceği görülmüştür. Öğrencilerin, cevaplarında ortaya koydukları yaklaşımlar, şu üç grup altına dahil edilebilecek özellikler taşımaktaır: İlk grupta, gençlerin yaşlılarla aralarında bir kuşak farkı ve çatışması olduğunu dile getiren cevaplar yer almaktadır. Bu cevapları veren öğrenciler, yaşlılarla aralarındaki bu kuşak farkından ve çatışmalardan şikayet etmektedirler. İkinci grupta toplanabilecek cevaplar ise, yukarıda verilen alışılmış kuşak çatışması anlaşmazlı̆̆ı meselesinin sınırlarını aşan, daha ağır bir soruna işaret etmektedir. Bu gruptaki öğrencilerin "yaşlılarda sevmedikleri özellikleri" sıraladıkları cevaplar; sert, dışlayıcı, hatta aşağılayıcı ve kimi zaman da düşmanca bir tutumu ortaya koymaktadır. Bu nedenle, ikinci grupta yer alan bu cevapların özellikle dikkatle analiz edilmesi gerektiği açıtır. Çok az sayıda öğrenciden oluşan üçüncü grupta ise, öğrencilerin, şikayet ettikleri yaşlı özelliklerine bir ölçüde empati ve anlayışla yaklaşma eğiliminde olduğu görülmektedir. Bu öğrencilerin cevaplarında daha olumlu ve yapıcı bir bakış açısı görülmektedir. Çalışmanın aşağıda yer alan bölümünde, burada ana hatlarıyla verilen bu üç gruba ait bulgu ve değerlendirmeler sırasıyla ayrıntılı bir şekilde ele alınacaktır:

Öncelikle, birinci grupla ilgili şu ayrıntılar öne çıkmaktadır: Birinci grupta yer alan öğrencilerin cevapları, bu gençlerin, yaşlılarla olan ilişkisinin çok zayıf olduğunu göstermektedir. Bu öğrencilerin cevapları, ana hatlarıyla, yaşlılar ve gençler arasında birbirini anlama, dinleme, tanıma ve sağlıklı bir iletişim kurma ve sürdürme konularında çok önemli eksiklikler olduğunu dile getirmektedir. Öğrenciler, bir yandan bu farkl1lıklardan ve yaşlılarla birbirlerini anlayamamaktan duydukları rahatsızlığı dile getirmekte; öbür yandan da, yaşlıların çeşitli hal ve davranışlarından da şikayet etmektedirler. Aşağıda, bu grubun yaklaşımını en belirgin şekilde örnekleyen bazı öğrenci cevapları ardı ardına sıralanarak sunulmaktadır. (Bu çalışmada yer verilen tüm 
öğrenci cevapları, tamamen öğrencilerin yazdığı biçimiyle sunulacaktır. Cevaplar, doğrusuyla-yanlışıyla, yazım ve ifade biçimlerine hiç müdahale edilmeden, tamamen öğrencilerin yazdığ şekliyle verilmektedir. Öğrencilerin duygu, düşünce ve fikirleri; yine öğrencilerin kendilerinin seçtikleri dil, ifade tarzı, duygusal ton, üslup, bilgi ve dil bilgisi birikimi içinde sunularak sıralanmaktadır. Dilbilgisi, noktalama ya da yazım hatalarına dahi müdahale edilmemiştir):

- "Yaşhlarda hoş bulmadığım bir ... özellik ... değişen dünyaya ayak uyduramayıp gelişen yeni nesili hoş görmemeleri ve kendi düşünce tarzların yeni nesle empoze etmeye çalışmaları"

- "Yaşllarm kendi dönemleri ile şimdiki dönemi karşılaştırıp memnuniyetsiz olması ve kendi dönemlerine göre bizimde şekillenmemizi istemeleri."

- "Zamanin koşullarnna ayak uydurmak istemiyorlar"

- "Kendi jenerasyolarmm en iyisi olduğunu şimdiki gençlerin çok bozulduğunu söyleyip insanlarm morallerini düşürmeleri"

- "her şeyin en iyisini bildiklerini iddia etmeleri ve sürekli öğüt vermeleri"

- "Kendinden daha genç bireyleri aşın sert bir şekilde eleştirme, yerme, aşă̆ılama"

- "her şeyi bildiklerini sanmalar. Cahilliklerini kabul etmiyorlar"

- "Kendilerini güncellememeleri. Bilim hakkında herhangi fikirlerinin olmamasi. Hayata tek açıdan bakmaları"

- "Hemen hemen hepsinin huysuz ve hayattan bezmiş olup hep kötü anılarmı anlatmaları"

- "Her şeye karışmalarını sevmiyorum"

- "geçmişe takılı kalmaları"

- "Yeni bir şey öğrenmeye çok kapalı olmaları"

- "her şeye karışmaları"

- "sürekli nasihat vermelerini

- "öğütvermesini sevmem"

- "çok konuşmalarmi sevmem"

- "Çok soru sormalarını sevmiyorum"

- "Çok konuşmalarmi sevmiyorum"

- "İnsanlara mesafeli durmalarnı sevmiyorum"

- "Dinlemeden konuşan dedim dediklik çocukça davranış" 
Bu grupta yer alan cevaplarda, gençler, yaşlıların geçmişte kalan bazı düşünce ve değer sistemlerine bağlı olduklarına vurgu yapmaktadırlar. Yaşlıların, "aksi", "inatçı", "huysuz", "geçimsiz" olduklarını öne sürmektedirler. Yaşlıların "gençleri anlamadıkları ve anlamak için çaba göstermedikleri" konusunu sıkça dile getirmektedirler. Ayrıca, yaşılıların "çok ve tekrarlı konuşmalarından" ve hatta "dedikoducu" olmalarından yakınanların sayısı da dikkat çekecek kadar yüksektir. Gençler ayrıca, "yaşlıların çok ilgi beklediğinden", "aşırı hassas ve alıngan olduklarından" ve "kendilerine acıyarak bakmalarından, kendilerine acındırmalarından" da şikayet etmektedirler.

Verilen cevapları değerlendirirken "ikinci bir grup" oluşturduğu fark edilen öğrenci cevapları ise, öncelikle, birinci grupta gözlemlenen "kuşak çatı̧̧ması" sorununu vurgulamaktadır. Fakat bu cevaplarda aynı zamanda, "kuşak farklılığı ve çatışması" tanımlarının da çok ötesine geçen başka ve çok daha olumsuz bir bakış açısı görülmektedir. Bu gruptaki öğrenciler, yaşl1larda sevmedikleri özellikleri sıralarken, kuşak farkı sonucu ortaya çıkan mesafeden ve iletişim zorluklarından şikâyetçi olmanın ötesine geçen bir rahatsızlık belirtmektedirler. Üstelik de öğrencilerin bazıları bu rahatsızlıklarını çoğu kez sert, saygıdan yoksun, ötekileştirici, ayrımcı, hatta kimi durumlarda nefret dahi içeren ve acımasız bir üslupla dile getirebilmektedirler.

Bu grupta, açıkça ortaya koyulan dışlayıcı bir yaklaşım görülmektedir. Yaşlıların, yaşlanma ve sağlık durumu etkisiyle yaşadıkları fiziksel bazı sorunlar "itici" bulunmaktadır. Hareket kısıtlılığı, görme ve işitme bozukluğu, hafiza kaybı, vb. zorluklar, zayıflıklar ve engeller rahatsız edici bulunmakta ve anlayışla karşılanmamaktadır. Bu grupta yer alan gençler, yaşlıları, günlük yaşam içinde varlığına dahi tahammül edilmesi çok zor olan ve istenmeyen kişiler olarak görmektedirler. Bu öğrenciler, bu tahammülsüzlüklerini ifade ederken, özensizce ve belki de bazen anlamını tam da bilemeden yanlışlıkla çok sert ifadeler kullanabilmektedir. Bu durum, gençlerle yaşlılar arasındaki ilişkiyi daha da kırıcı ve saygıdan yoksun bir hale getirmektedir. Yine hiçbir müdahalede bulunmadan, tamamen öğrencilerin kâğıtlarından alındığı biçimiyle, tüm yazım özellikleri ve yanlışları ile birlikte, bu yaklaşımı örnekleyen birkaç görüş aşağıda sunulmaktadır:

- "Yaşlllarda sevmediğim şey çoğunun dişleri yok yemek yerken yanlarında olmak istemiyorum"

- "Ben yaşlılarda yemek yerken çıkardıkları şapırtı sesini seomiyorum" 
- "A ̈̆̆zlarmı şapırdatmalarmı seomem."

- "Babaannemin yemek yerken takma dişlerinden ses çıkarması ve ağzını şapurdatması".

- "Dedemin çorbayı ses çıkararak içmesi ve her şey hakkında çok fazla soru sorması"

- "hijyen kurallarnna uymamalar"

- "Az banyo yapip kokmaları (kişisel temizlik)"

- "Midesinde sorun olduğu için yemekte geğiriyor"

- "Çok ıslak öpmeleri" ... "sulu öpmelerini seomem"

- "Sesli balgam çıkarıp yere tükürmeleri"

- "yaşlılarm yolun ortasında balgam çıkarı yola atmasından rahatsızlık duyuyorum"

- "Burun ve kulak karıştırmaları (toplum içinde)"

- "Gaddarlik"

- "ukalalık"

Bu cevapların yer aldığı gruptaki öğrenciler, çevrelerindeki yaşılıları, saygı ile yaklaşılması gereken birer yetişkin birey olarak görmediklerini ortaya koymaktadırlar. Yaşlıları, birer yük ve sorun olarak gördüklerini ifade etmektedirler.

Bu yaklaşımı gösteren bu ikinci grubun ifade ettiği diğer bir yaygın yorum ise, yaşlıların yaşadıkları sağlık sorunları ve buna bağlı ihtiyaçları ile ilgilidir. Bu öğrencilerin bazıları, yaşlıların, yaşlılıklarını ve sağlık sorunlarını, gençler üzerinde bir baskı unsuruna dönüştürdüklerini ifade etmektedirler. Yaşlıların, sağlık durumlarını bir "suistimal" malzemesi olarak kullandıklarını iddia etmektedirler. Böylece, yaşlıların bu özelliğinin kendilerine yük olduğunu dile getirmektedirler. Bu görüşü örnekleyen birkaç cevap aşağıda verilmektedir:

- "Ben yaşhlarm kendilerini actndırmalarmı seomem"

- "Sağhlğı yerinde olup, kendi işini yapabilecek durumdayken hastaymış gibi davranıp ailesini sürekli kendisine bakmak zorunda bırakan yaşllardan hoşlanmıyorum"

- "Hastalik hastası olmaları sürekli oram buram ă̆rıyor demeleri"

- "Yaşlıların hastalık hastası olmasını sevmiyorum yaşlandıklarmı çok çabuk kabul edip o modda davraniyorlar" 
- "Aslında iyiyken, hasta değilken hastaymış gibi yapmaları"

- "Yaşlanmanın getirdiği fiziksel olumsuzlukları barındırmasa da bunu bahane ederek iyi niyet suistimali"

Bu yaklaşıma sahip öğrenciler, yaşlılıkla birlikte kaçınılmaz olarak ortaya çıkan fiziksel zayıflıkları, engelleri ve sağlık sorunlarını, yaşlı insanı "mağdur eden" bir sorun değil de yaşlıların kendi "kabahati” gibi görmektedirler:

- "Zor duymalari beni rahatsiz eder."

- "işlerine geleni duyup, istemediklerini duymamaları"

- "Yavaş olmalarından hoşlanmam."

- "Unutkanlikların sevmem"

- "Yaşhlarda unutkanlık beğenmediğim bir hastalık"

- "Çok sese katlanamamak"

- "bağırarak konuşuyorlar"

- "Hastalanmaları"

- "Sürekli hastalıklarndan bahsetmeleri"

- "Çok geç hareket etmeleri"

Bu yaklaşım, toplumda zaman zaman karşılaşılan, "engelli ve yaşlıların evlerinde oturması ve toplum içine çıkmaması gerektiği” yönündeki yanlış ve haksız tutumu yansıtmaktadır. Yine ikinci grubun bir bölümü de, yaşliların, dışarıda, sosyal yaşam içinde, kamusal alandaki varlıklarını da rahatsız edici bulmaktadır. Buna en belirgin ve yaygın örnek, yaşlıların toplu taşıma araçlarını kullanmalarından duyulan rahatsızlık olarak ortaya çıkmaktadır. Hatta, bazı durumlarda, yaşlıların dışarıda yaya olarak dahi bulunmaları bir rahatsızlık unsuru olarak görülmektedir. Örneğin:

- "çok gezip otobüsleri işgal etmeleri"

- "Yaşliların toplu taşımada yer kapmak için etrafa sataşmalarından hoşlanmıyorum"

- "Toplu taşıma araçlarında sürekli gençleri eleştirmeleri. Bizimde bazı sebeplerle çok yorgun olduğumuz zamanlar olabilir. Bunla düşünmeden yorum yapmaları"

- "Gençlerden toplu taşımada yer, sırada öncelik beklerken öğrencilere evlerine kiraya vermek istemezler." 
- "Yaşllarm yaya yolundan giderken ortadan gidip kimseye yer vermemesi. Olur olmadik yerde birden durup yolu kapatıp düşünmeleri"

Bu grupta yer alan öğrencilerin cevaplarından, yaşlıların yalnızca dışarıda, sosyal yaşam içinde değil, ev içindeki ortak yaşam alanlarında da rahatsızlık verici "yükler" olarak görülebildikleri anlaşılmaktadır. Örneğin, yaşl1ların, "TV seyrederken sürekli kanal değiştirtmek istemeleri"ni sevmediğini belirten öğrencinin cevabı bu tutumu yansıtmaktadır. Ev ve ortak yaşam alanları içinde, aile bireylerinden herhangi birinin bir isteği ya da tercihi normal karşılanabilecekken, bir yaşlının aynı tercihi belirtmesinin bir hak olarak görülmediği anlaşılmaktadır. Bu gruptan öğrencilerin, hem sosyal yaşam içinde hem de evde özel ortak alanlarda tahammül edemedikleri yaşlı bireyleri saygın birer yetişkin olarak görmedikleri anlaşılmaktadır.

Öğrencilerden bazılarının ise, yaşlıları, yalnızca gençlerin ihtiyaçlarını karşılayabilecek, yararlanılabilecek birer kaynak olarak gördükleri anlaşılmaktadır. Bu öğrencilerin, bu beklentileri gerçekleşmediği zaman, yaşlılara karşı daha da sert bir tutum takınabildikleri görülmektedir. Yaşlıların "sanki cebinde akrep var gibi cimrileşmeleri" ni sevmediğini belirten öğrencinin tutumu bu durumu örneklemektedir. Yaşlıların "çirkef olmaları"ndan rahatsız olduğunu belirten bir diğer öğrencinin cevabı da aynı sert yaklaşımı yansıtmaktadır. Yaşlıların konuşmasını, kendilerini cevaplamasını, "çemkirme" olarak tanımlayan öğrenci cevabı da bu doğrultudadır.

Sayıları çok az olsa da, "üçüncü bir grup" oluşturduğu görülen öğrenci cevapları ise, birinci ve ikinci gruplardan farklı bir yaklaşım ortaya koymaktadırlar. Bu öğrencilerin, yaşlıların durumu ile ilgili daha anlayışıı bir yaklaşıma sahip oldukları görülmektedir. Bu grubun cevaplarında, yaşlıları anlama çabası, durumlarına ve sorunlarına hassasiyet gösterme gibi bazı özellikler öne çıkmaktadır.

Bu üçüncü grupta yer alan öğrenciler, yaşlıların sosyal yaşamın dişında kalmalarından üzüntü duyduklarını ifade etmektedirler. Yaşlıların toplumdan soyutlanmalarını ve yalnız kalmalarını doğru bulmadıklarını söylemektedirler. Örneğin, bir öğrenci şöyle demektedir: “Genel olarak ülkemizde yaşlılar aktivite ve sosyal hayatın dışında hareket ediyorlar bu durumu yanlış buluyorum". Bu yaklaşımı ortaya koyan öğrenciler, yaşlıların yaşamdan el etek çekmelerini, kendilerine güvenmemelerini, sosyal ve kültürel her türlü faaliyetten ve diyalog ortamından mahrum olmalarını üzücü bulduklarını 
dile getirmektedirler. Yaşlıların daha fazla yaşamın içinde olmasını istediklerini belirtmektedirler. "Yaşlıların kendilerini küçük görmelerinden rahatsız oluyorum" diye cevap veren öğrencinin tutumu bu durumu yansıtmaktadır. Bu öğrenciler, yaşlıların kendi birikim ve becerileri ile ilgili özgüvensiz olmalarından üzüntü duyduklarını ifade etmektedirler.

$\mathrm{Bu}$ açıdan bakan öğrencilerin bazıları da, ikinci grubu hatırlatan bir şekilde yaşlılardan şikayet etmekte ve onlarla ilgili rahatsızlık duyduklarını dile getirmektedirler. Fakat, ikinci grubun yaklaşımından farklı olarak, üçüncü grubun şikayetleri aynı zamanda bir ölçüde empati çabasını da içermektedir. Durumla ilgili olarak duydukları üzüntüyü ve anlayışı da ortaya koymaktadır. Bu yaklaşımı örnekleyen bu üçüncü grup cevaplarından bazıları, yine tüm önceki cevap alıntılarında da olduğu gibi, tamamen öğrencilerin kendi yazımları, ifadeleri ve yazım hataları korunarak aşağıda sıralanmaktadır:

- "Yaşım var gibi düşünüp elini ayağımı her şeyden çekmeleri biraz canımı sıknyor. Aslında bunu her insan için gereksiz olduğunu düşünüyoruz. Belki rahatsılıkları vardır ancak ona uygun bir şeyler bulabilirler. Tabiki yardımlarımızla : )"

- "biraz fazla konuşuyorlar ama o da ileşim kurmaya çalıştıkları için gün içinde genelde yalnız kaldıklarn için bu konuda hak veriyorum"

- "Biliyorum ki özellikle eşi vefat etmiş olanlarda yalnızlık daha çok yaşıyorlar. Bu yüzden yanlarnna biri geldiğinde sürekli konuşuyor ve dönüp dolaşıp aynı anıları anlatıyorlar. Insan bir yerden sonra sıkılyyor ama tabii ki empati kurup anlamalıyız. Eskiden daha çok rahatsızdım ancak şu an daha olumlu düşünüyorum."

Yine bu üçüncü grupta yer alan cevaplardan dikkate değer bir kısmı ise, öğrencilerin yaşlılarda toplumsal cinsiyet eşitsizliği konusunda duydukları rahatsızlığı ve üzüntülerini dile getirmektedir. Bu yöndeki cevapların, erkek ve kadın öğrenciler arasında hemen hemen eşit dağıldığı görülmektedir. Bu öğrenciler, yaşıılığın getirdiği soyutlanmaya ve yalnızlığa ek olarak, yaşlı kişinin bir de cinsiyeti açısından, yani kadın olması nedeniyle yaşadığı zorluğa dikkat çekmektedirler. Çok önemli bir farkındalığa işaret eden bu yaklaşıma örnek olarak, aşağıda verilen şu cevaplar dikkate değer niteliktedir: 
- "Mesela anneannemin her şeye susup kendini savunmast gereken zamanda savunamaması, içine atıp kendi kendine üzülmesini istemiyorum. Kendi ayaklarn üzerinde duramayan güçsüz bir kadının erkekler veya çocukları karşısında ezilmesini istemiyorum"

- "Tanıdı̆̆ım bir kişi 74 yaşında ve yetiştirilme şeklinden dolayı eşini bazı konularda fazlasıyla yermesi. Genel olarak kadinları ezmeleri yani."

Bu öğrenciler, yaşlı bireylerin ayrımcı ataerkil bakış açısına sahip olabildiğini dile getirmektedirler. Üstelik, eleştirdikleri bu bakış açısının hem kadın hem de erkek yaşlı bireylerde görülebildiğini ifade etmektedirler. Örneğin, bir öğrenci şöyle söylemektedir: “Bazı yaşlılar erkek ve kız çocuk ayrımı yapıyor ve ben bunu doğru bulmuyorum". Bu üçüncü grup üyeleri, baskın ataerkil toplum düzeninde "erkek" bireylerin tutum ve davranışlarını eleştiren cevaplar da vermektedir. Örneğin, aşağıdaki cevapları veren öğrenciler, öfkelerini sert bir şekilde yansitmaktadırlar:

- "Eşinden boşanmış dul erkeklerin daha kırkı çıkmadan yeni bir eş arayışına girmeleri"

- "Yaşlı bazı erkeklerin genç kızlara öküz gibi bakmalarından nefret ediyorum."

\section{Tartışma, Değerlendirme ve Öneriler}

Çalışmanın bundan sonraki bölümünde, örneklem grubu öğrencilerinin yaşlılarda eleştirdikleri özellikleri ifade ederken gösterdikleri olumsuz ve bazen de açıkça dışlayıcı tutuma sebep olan faktörler ele alınacaktır. Bu faktörler anlaşılmaya çalışılacak ve saptanan sorunların çözümlenebilmesi için bazı öneri ve değerlendirmeler sunulmuştur.

Öncelikle, bu üç türden yaklaşımla ilgili olarak ele alınabilecek en önemli noktalardan biri, her üç grubun da ortak olarak ifade ettiği "iletişim kopukluğu ve kuşak farklılığı" meselesidir. Genç ve yaşlı kuşaklar arasındaki bu kopukluk ve mesafe çok büyük bir önem taşımaktadır ve toplumun tamamının iyiliği için mutlaka çözümlenmeye ihtiyaç duymaktadır. Çünkü, Lofti, Sabour ve Ghasemlou'nun da belirttiği gibi, "Kuşaklararası çatışma aslında toplumsal çatışmadır" (Lofti, Kabiri ve Ghasemlou, 2013, s.96). Bu nedenle de, hem bireysel ilişkilerin ve toplumsal ilişkilerin sağlıkı olabilmesi, hem de 
toplumsal yapının bir bütün olarak sağlıklı işlemesi açısından kuşaklar arasındaki sorunların giderilebilmesi zorunludur. Bu tür çatışmalar, daha önce de belirtildiği gibi, sadece tarafların kişisel ve sosyal durumlarına değil, tüm toplumun sosyo-kültürel, ekonomik, siyasal yapısını olumsuz etkilemektedir. Bu nedenle de, bu türden çatş̧malar, tüm toplumun bedensel ve ruhsal sağlığına da zarar vermektedir. Canatan'ın da belirttiği gibi,

... bütün yaş gruplarmmn toplumsal yaşama ve toplumsallaşmanm sürdürülmesine karşıllkh olarak katkllar vardır ve hiçbiri ihmal edilebilir değildir. Ancak büyük bir hizla gerçekleşen toplumsal değişme sürecinde özellikle yaşlılarm biriktirdikleri deneyimler çok kıymetlidir ve toplumun devamı açısindan kültürel rehber konumundadır. Bu nedenle, toplumsal değerleri korumak ve sürdürmek için kuşaklar arası ilişkileri güçlendirecek, aktarımları kolaylaştıracak yaşlı ve genci, yaşl ve çocuğu bir araya getirecek projelerin geliştirilmesi önemlidir." (Canatan, 2008, s.69).

Gençler ve yaşlılar arasında mevcut olan ve çalışmanın ilk bölümünde sunulan örneklem öğrenci grubu cevaplarının da yansıttığı kopukluk, ciddiyetle ele alınıp çözümlenmeye ihtiyaç duyan bir sorundur. Bu iletişim kopukluğu sorununun sinurlar ötesi nitelikte olması da durumun ciddiyetini vurgulamaktadır. Örneğin, İrlanda'da yayımlanan "Gençlerin Yaşlanmaya ve Yaşlılara Yaklaşımı" başlıklı bir raporda yer alan bir bilgi, gençlerle yaşlılar arasındaki iletişimin azlığını ya da hiç mevcut olmadığını göstermesi bakımından dikkate değer niteliktedir. Bu raporda, bir örneklem grubu oluşturan gençlere, hayatlarında (aile ya da okul çevresindeki yaşlılar dışında), yaşlılarla herhangi bir sosyal iletişim ya da ilişkilerinin olup olmadığı sorulduğunda, gençlerin yüzde altmış altısı, tek bir yaşlı birey ile bile herhangi bir iletişimlerinin olmadığını belirtmişlerdir (Power, 1992, s.19-20).

Kuşaklar arasındaki uzaklığa sebep olan ve toplumun tüm yaş gruplarıyla bir bütün olarak sağlıklı işleyişini engelleyen koşulların neler olduğunu saptamak, önemli bir başlangıç olacaktır. Bu koşulları incelerken ortaya çıkan önemli konulardan biri, önyargılardır. Yaşlılarla ilgili önyargılar, kalıpyargılar ve yanlış inanışlar, toplumdaki yaşlı algısını büyük ölçüde belirlemektedir. Çünkü, gençlerin yaşlılarla ilgili olarak şikayetçi oldukları, hatta bazen de küçümseyerek dışladıkları bazı özelliklerin çoğunlukla sadece yaşlılarla 
ilgili bazı önyargılardan ibaret olduğu görülmektedir. Hatta yaşlılığın ne olduğu ve ne zaman başladığı konusunun bile toplumdan topluma ve kültürden kültüre farklılık gösterdiği düşünülecek olursa, "yaşlı" algısının kurgusal niteliği anlaşılacaktır. Bunun bir sonucu olarak da, aslında mücadele edilmesi gereken asıl faktörün önyargılar olduğu görülecektir. Kenan Çayır'ın da belirttiği gibi, "Yaş kategorileri birer toplumsal kurgudur" (Çayır, 2011, s.2). Buna bağlı olarak, belli yaştaki bireylerin nasıl davranması ve yaşaması gerektiğine dair tanımlar da birer kurgu olarak ortaya çıkabilmektedir. Yaşlılık tanımlarının kültürlerarası değişiklik gösterdiğini ele alırken, Çayır şu örneği vermektedir: "Türkiye'de insanlar gençliğin 34,2 yaşında bittiğini, 55 yaşından sonrasının ise yaşl1lık dönemi olduğunu düşünmektedirler. Buna karşın Yunanlıların yaşlılığın 68 yaşında başladığını düşünmeleri, iki komşu ülke arasında bu açıdan büyük bir kültür ve algı farkı olduğunu göstermektedir." (Çayır, s.3) Benzer şekilde, "yaşlılık" tanımlarının kültürden kültüre değişebildiğine vurgu yapan Wilfried Ferchhoff tartışmasını Hipokrat'a, Roma ve Orta Çağ tanımlarına gönderme yaparak derinleştirir:

Tüm tarihsel çağlarda ve kültürlerde, en azından antik çağdan itibaren insan ömrünün dönemleri, yaşam aşamaları değişik kavramlarla belirtilmiş ve her zaman kesin ve açı sınıflandırmalar yapılmamıştır. Hipokrat, Çocuk (paidion), oğlan (Pais), delikanlı (Ephebos), genç erkek (neaniskos), adam (aner), yaşlı adam (presybytes)'dan moruka (geros)'a kadar yaşları sinıflarken, Romalılarda yaşamı üçe veya dörde bölme düşüncesi hakimdi. Orta Çağ Avrupa'sında yaşam evrelerinin yedi, hatta sekize bölündüğünü görüyoruz: 7 yaşına kadar infantia, 14 yaşına kadar pueritia, 15 ile 28 arası adolencentia, 29 dan 49 kadar iuventus ve 50 den 77'ye kadar senectus ve sonrasında ölüme kadar senium kavramları kullanıldı. (Ferchoff, 85)

Ait oldukları dönemlerin ataerkil düzenlerini yansıtan bir şekilde tamamen eril kavramlar üzerinden yapıldığı dikkat çeken bu bölümlemelerin yüzyıllar içinde ve farklı coğrafyalarda pekçok değişime uğradığı görülmektedir.

Bununla birlikte, toplumda yaşlıların nasıl davranması ve yaşaması gerektiğine dair oluşan tanımlar büyük ölçüde bu türden bölümlemelere dayalı olarak üretilmiştir. Çoğunlukla genellemelere dayalı bu türden toplumsal önyargılar, yaşlı bireylerin gerçekliğini yansıtmayan, kurgusal bir yaşlı ve yaşlılık tanımı ortaya koyabilmektedir. Sonra da yaşlıların özelliklerini, toplumdaki yerini ve rolünü, bu kurgusal tanımlar gerçekmiş gibi kabul ederek belirlemektedir. Bunlar toplumda, hiç sorgulanmadan kabul gören gerçekler 
olarak süregelmektedir. Yaşlilara uygun görülen bu kurgusal rollere şu birkaç yaygın örneği sunmakla başlanabilir:

- Yaşlılar geçmişe dönük ve gelişime kapalıdır.

- Gençleri anlayamazlar.

- Yaşlların bilgileri eskimiştir; bugünün gerçekliğinden kopuktur.

- Yaşlılar her zaman ağırbaşııdırlar; ağırbaşlı olmalıdırlar.

- Yaşlılar hem zihinsel hem de fiziksel olarak yavaşlamışlardır ve bu nedenle de sosyal hayatın dışında kalmışlardır.

- Yaşlıların zihinleri hep bir ölçüde bulanıktır ve bu nedenle de kavramaları yetersizdir.

- Yaşlıların cinsel hayatı yoktur.

- Yaşlılar bakıma muhtaç ve bağımlıdırlar. vs...

"Yaşılıkla İlgili Yaygın İnanç, Tutumlar ve Sağlık Hizmetlerine Yansıması" başlıklı çalışmalarında Özlem Sinan ve Naile Bilgili'nin de ifade ettiği gibi:

Toplumuzda yaşh olarak; bakıma muhtaç, olumsuz fiziksel ve ruhsal değiş̧ikliklerin görüldüğ̈̈, huzursuz, uyumsuz ve sosyal ilişkileri zayıf bireyler akla gelebilmektedir. Genellikle yaşlanma sürecinin olumlu yönleri ihmal edilmekte ve yaşlılık ile ilgili olumsuzluklar ön plana çıkarlarak sağhlklı yaşlanma süreci geçiren bireyler göz önünde bulundurulmamaktadır ... Bu toplumsal yargılar yaşl bireylerin yaşamlarn üzerindeki kontrollerini kaybetme ya da toplumdan dışlanma gibi çeşitli korkular yaşamasına neden olmaktadır. Fiziksel gü̧̧ kaybı ve bedeninde değişen durumlara uyumda güçlükler yaşayan yaşlı birey, aynı zamanda toplumun beklentilerine uyum sağlamaya çalışmaktadır ... Yaşl bireylerin, toplumun kendilerine yüklediği olumsuz özellikleri içselleştirerek yaşamlarna yansıtmalarn ve günlük ihtiyaçlarn karşlanmasında bir başkasına bağımlı olma korkular yaşam kalitesinin olumsuz etkilenmesine neden olmaktadır. (Sinan ve Bilgili, 2019, s.247).

Bu türden inanışlar toplumda yerleştikçe ve yaşlılardan bu önyargılar doğrultusunda davranmaları beklendikçe, yaşlı bireyler de bu beklentiye uyma eğilimi göstermektedirler. Bunun bir sonucu olarak da, yaşı bireyler 
aktif yaşamdan giderek geri çekilmektedirler. Böylece, kurgusal birer önyarg1 olan fikirler, yaşlıların gerçek hayatını şekillendirmektedir. Sonuç olarak, toplumsal düzen de bu etki altında belirlenmektedir. Yaşllara dair yerleşen önyargılar da böylece giderek daha da güçlenmekte ve yerleşmektedir. Yaşlılar, giderek aktif toplumdan ayrı bir grup olarak sınırlandırılmaktadır. Üstelik, yaşlıların yaşamdan kopuk olduğu önyargısı, farklı kültür ve coğrafyalarda da görülebilen yaygın bir sorundur. Örneğin, Roux, Gobet, Clemence, Höpflinger, bambaşka bir kültür olan İsviçre kültüründe de "yaşlıların yalnız, izole ve bağımlı yaşadıkları" şeklinde bir önyargının olduğunu vurgular (1996, s.161). Toplumun bu kadar dışında ve pasif tahayyül edilen yaşlı bireyler; ayrımcllı̆a maruz kalan tüm dezavantajlı grupların bireyleri gibi, suistimale de açık olarak algılanmaktadır. Sema Buz'un ifadesiyle, "İstismar etme önemli diğer bir yaş ayrımcılığı tutumudur. Cinsel, fiziksel, finansal açlardan yaşlılar zarara uğratılabilir." (Buz, 2015, s.271) Yaşlı, bu açıdan da zayıf, savunmasız ve korunmaya muhtaç olarak algılanır.

Türkiye İstatistik Kurumu verilerine göre, Dünya nüfusunun \% 9,1'ini, Türkiye nüfusunun ise \% 8,7'sini oluşturan yaşlı nüfusu bu kadar pasif ve etkisiz olarak tanımlayan bu yaşlı imajı, yalnızca yaşlı bireylere değil, toplumun bütününe de zarar vermektedir. Bu nedenle, her yıl daha da büyüyen bu sorunun giderilmesine yönelik olarak ciddi bir değerlendirme yapmak ve çözüm önerileri ortaya koymak büyük önem taşımaktadır.

Bu sorunun çözümüne katkı sağlayabilecek değerlendirme ve öneriler düşünülürken, en başta ele alınması gereken faktörlerden biri "aile ortamı" olarak ortaya çıkmaktadır. Aile ortamında bilgi ve farkındalık kazanma konusu ciddiyetle ele alınmalıdır. Çocuğun içinde yetiştiği aile ortamındaki tutum ve davranışlar, gencin yaşlılara karşı daha sonraki tutumunun belirlenmesinde çok önemli bir yer tutmaktadır. Çalışmanın ilk bölümünde ayrıntıyla verilen genç cevaplarını, büyük ölçüde, bu gençlerin şahsi ve aile içi özel hayat gözlemlerine ve tecrübelerine dayanmakta olması dikkat çekicidir. Gençlerin gözünde yaşlılığın ve yaşlıların nasıl algılandığı konusu, büyük oranda, daha çocukluk aşamalarından itibaren aile içindeki gözlem ve öğrenme süreçle-

\footnotetext{
${ }^{1}$ Bu makalenin kaynakçasında yer alan yabancı dildeki kaynaklardan yapılan alıntıların çevirileri makale yazarı tarafından yapılmıştır.
} 
rinde belirlenmektedir. Bu açıdan, anne ve babaların, çocuklarının gözlemlediği tüm ortamlarda, ailedeki ya da çevredeki yaşlı bireylere nasıl yaklaştığı çok önemlidir. Çocuk, anne ve babasının yaşlılara nasıl yaklaştığını gözlem yoluyla öğrenecektir. Çocuk, ailesinin yaşlılara ayrım gözetmeden saygiyla mı yoksa onları bir yük olarak gören bir tarzda mı yaklaştığını görerek öğrenecek ve benimseyecektir. Sonra da, bu öğrendikleri çocuğun gelecekte bu konudaki tutumunun temel belirleyici unsuru olacaktır. Bu tutumda daha sonra eğitim yoluyla farklılaşmalar olabilse de, ailede edinilen temel yaklaşımin etkisi devam edecektir. Ailenin bu anlamdaki model olma etkisini vurgulayan Çiftçi'nin de belirttiği gibi:

Ana-babanın değişik davranış kalıplarına sahip olması, çocukların da zamanla bilerek veya bilmeyerek bu kalıplan benimsemelerine yol açar... Çocuğun annesiyle kuracağı ilişki, onun, ömrü boyunca kuracağ insan ilişkilerinin temelini oluşturur. Bu nedenle psikologlar çocuğun aile içinde geçen (06) yaşının üzerinde dururlar. Yapılan araştırmalar bir çocuğun bu dönemde aldığı eğitimin, ondan sonraki eğitimine temel teşkil ettiğini ortaya koymuştur. (Çiftçi, 1991, s.3)

Bu nedenle de, yaşlılara karşı aile içinde başlatılıp geliştirilen önyargılar, kalıpyargılar ve yanlış inanışlar sorunu, kritik bir öneme sahiptir. Çocukluk aşamasında ailede edinilen tutum ve davranışlar, daha sonra eğitim kurumlarında, sosyal yaşam içinde, gelenekler ve toplumsal kurallarla, medyada ve daha pekçok toplumsal ve kültürel alanda güçlendirilmektedir. Bu nedenle de, bu aşamaların her birinde bu açıdan iyileştirilmeye gidilmelidir.

Öncelikle, ailelerin bu konuda bilgi ve farkındalık kazanmasına yönelik çalışmalar yapılmalıdır. Bu gibi konularda önemli çalışmalar yapan ve destek sunan "Aile, Çalışma ve Sosyal Hizmetler Bakanlığı"nın aile eğitim programları listesinde "yaşlılık ve yaşlılarla iletişimimiz" konularına da özel bir yer verilmesi çok yararlı olacaktır. Bu konularda yapılacak yayın ve programlara bireylerin ulaşabilmesinin sağlanması; özellikle de anne-babaların bu kaynaklar üzerinden bilgilendirilmesi çok faydalı olacaktır. Bu bakanlık şemsiyesi altında Büyük Şehir ve diğer belediyelerin de bu türden eğitim faaliyetlerine katkı sunmaları ile faaliyetin tüm ülkeye yayılması sağlanmalıdır. $\mathrm{Bu}$ çerçevede, Yaşlılık ve Yaşlanma Bilimi (Gerontoloji) bölümlerinde lisans eğitimi almış üniversite mezunları, bu önemli faaliyetin asıl uygulayıcı ve eğiticileri olmalıdır. Ataması Aile, Çalı̧̧ma ve Sosyal Hizmetler Bakanlığı tarafından yapılacak Yaşlılık ve Yaşlanma Bilimi (Gerontoloji) bölümü mezunları 
bu belediyelerde görevlendirilmelidir. Bu konuda, kanun yapıcıya ve yürütme organına bilim insanlarının katkısı gecikmeden sunulmalıdır.

Çocukların, aile içinde öğrendiklerinin gelişeceği alan, eğitim kurumlarıdır. Bu nedenle, çözüm önerilerine konu olarak, aileden sonra ele alınması gereken alan, eğitim kurumları olacaktır. Bu bağlamda, öncelikle, çocuklar ilköğretime başladıkları andan itibaren, kendilerine sunulan müfredatta, "yaşlılık", "yaş alma" ve "yaşlanma" konularını tanıtan konu başlıklarına yer verilmelidir. Böylece öğrencilerin bu kavramlar konusunda temel bilgi ve farkındalık kazanması sağlanmalıdır. Buna paralel olarak; ilköğretim aşamasında, örneğin her yarıyılda bir kez olmak üzere, yaşa göre hazırlanmış çok sade yaşlanma ve yaşlılıkla ilgili bilgilendirici faaliyetler organize edilebilir. Bu bilgilendirme faaliyetlerinin, Aile, Çalışma ve Sosyal Hizmetler Bakanlığı bünyesinde, Yaşlanma ve Yaşlılık Bilimi (Gerontoloji) Bölümü mezunları tarafından organize edilmesi, başarılı olunmasına büyük katkı sağlayacaktır. Yine bu bilgilendirme faaliyetleri çerçevesinde, Yaşlanma ve Yaşlılık Bilimi çalışanlarını birikimleri doğrultusunda ve kontrolünde, yaşlı bireylerle gençlerin bir araya getirilmesini amaçlayan buluşmaların gerçekleştirilmesi de çok yararlı olacaktır. Yukarıda tanımlanan ders ve bilgilendirme oturumlarına, belli aralıklarla, yaşlı bireyler davet edilerek, kendilerinin meslekî ya da genel anlamda hayatla ilgili tecrübelerini öğrencilerle paylaşmaları sağlanabilir. Örneğin, "okul temelli kuşaklararası dayanışma modelleri"ni ayrıntısı ile tartıştığı makalesinde Filiz Yıldırım, gençlerle yaşılıarı müfredat kapsamında verimli bir şekilde biraraya getirme yöntemlerini tanımlarken şöyle der:

Bu model kapsamında yaşlıların eğitime yönelik alan deneyiminden yararlanılmaktadır. Bu amaçla yaşlılar; okullarda öğretmen, kütüphane ya da kafeterya görevlisi, idari personel yardımcısı, kariyer danışmanı, matematik ya da ya da herhangi bir derse ilişkin gönüllü kurs veren, dinleyici, öğretmen, ders asistanı gibi daha pek çok rolü gerçekleştirerek çocukların yaşamına dahil olmaktadırlar. Bu modellerde sıklıkla spor, sanat, müzik, yabancı dil dersleri ve uyuşturucuyu önleme ve buna yönelik eğitim programları için yaşllar tercih edilmektedir. Bununla birlikte yazı yazmayı öğretme gibi akademik amaçlar konusunda da yaşlılar öğrencilere yardımcı olabilmektedirler. (Yıldirım, 2015, s.281) 
Aynı şekilde, ilköğretim sonrası aşamalarda da, hiç kopukluğa uğratmadan, Yaşlanma ve Yaşlılık ile ilgili bilgi ve farkındalık sağlayacak ders ve faaliyetler sürdürülmelidir. Meslek Lisesi ve Lise seviyesinde, müfredata, örneğin sosyoloji derslerinin içine yerleştirilerek, Yaşlanma ve Yaşlılık bilimini tanıtacak konular, öğrencilerin ilgisini uyandıracak şekilde dahil edilmelidir. Ayrıca, eğitim kurumlarının müfredatları ve sosyal faaliyet planları çerçevesinde, öğrencilerle birlikte her yıl bir veya iki defa Huzur Evi ziyaretleri düzenlenmesi, öğrenciler üzerinde etki bırakacak bir farkındalık kazanma ve öğrenme vesilesi olacaktır. Yine okullardaki dersler ve faaliyetler bünyesinde, belli aralıklarla, yarım günlük organizasyonlar yapılabilir ve bu organizasyonlar kapsamında, her kesimden yaşlı bireyler okullara davet edilerek öğrencilerin birer ikişer bu yaşlı bireylerle görüşmeleri teşvik edilebilir. Bir diğer faaliyet ise, Lise seviyesi eğitim ve öğretimde her branş dersinin senede bir veya iki kere konunun uzmanı yaşlı, emekli öğretmen veya öğretim üyeleri tarafından verilmesi olabilir. Böylece gençler emekli eğitmenlerinin bedensel, zihinsel aktivitelerinin yerinde ve yeterli olduğunu görecekler ve onlardan öğrenecekleri çok şey olduğunu bizzat yaşayarak öğreneceklerdir.

Geliştirilerek sayıları arttırılabilecek bu türden uygulamalarla; hayatın doğal akışı içinde birbirinden kopuk, uzak, hatta habersiz olabilen gençlerle yaşlılar, birbirini tanıyacak ve yakınlaşabileceklerdir.

Aile ve eğitim kurumları dışında, sosyal yaşam içinde ve kamusal imkanlar çerçevesinde de çözüme katkı sağlayacak girişimlerde bulunulabilir. İlk olarak, çok önemli bir kurumsal yapılanma ögesi olarak; Aile, Çalı̧̧ma ve Sosyal Hizmetler Bakanlığı desteği ve denetiminde, büyük şehir belediyeleri ve tüm belediyeler bünyesinde, Yaşlanma ve Yaşlılık Daire Başkanlığı veya Müdürlüğü benzeri birimler oluşturulabilir. Halen birçok belediye yaşlılara hizmet vermektedir ve bu hizmetler çok yararlı ve değerlidir. Hali hazırda verilmekte olan bu hizmetler kapsamında, yaşlı bireyler için dinlenme ve sosyalleşme ortamları sağlanması, günlük hayatlarını sürdürme konusunda yardıma ihtiyaç duyan yaşlılara destek olunması, sağlık ve bakım hizmetleri sağlanması gibi pek çok önemli katkı sunulmaktadır. Tüm bunlar arttırılarak, çeşitlendirilerek devam etmelidir. Bunlara ek olarak ise, özellikle yaşlılarla gençleri biraraya getirecek faaliyetleri de bu hizmetlere dahil edebilmek çok önemli olacaktır. Belediyelerde, özellikle Yaşlılık ve Yaşlanma konusuna odaklanmış ve bu başlık altında faaliyet gösteren birimler oluşturulmalıdır. 
Tüm bu faaliyetler, bu birimlerin bünyesinde ve koordinasyonunda gerçekleştirilmelidir. Bu anlamlı ve gerekli çabalar tüm ülkede evrensel bilimin ışığında, belli ilke ve ölçütler çerçevesinde ortak olmalı ve doğal olarak halkının gelenek ve göreneklerine de saygılı olmalıdır. Bu gibi oluşumlar aracılığı ile ve sayg ve değer verme temelinde yaşlılara ulaştırılacak bu hizmetler, yaşl1ların gözünde de özel manevi bir tecrübe olacaktır ve kuşaklar arası çelişkileri azaltmaya katkıda bulunacaktır.

$\mathrm{Bu}$ hizmetlerde, belediyelerin organizasyonunda ve kontrolünde, hem lise ve üniversite öğrencileri, hem de sözkonusu belediye sınırları içinde yaşayan bölge sakinlerinden seçilecek istekli ve gönüllü gençler, ücretli ve/ya ücretsiz olarak katkı sunabilirler. Bu şekilde bu çalışmalara dahil edilecek olan gençlere, belli bir düzende bu gençler biraraya getirilerek eğitimler sunulmalı ve çalışmaların içeriği ve gereklilikleri ile ilgili temel bilgiler verilmelidir. Böylece, gençlerin yaşlılarla bir araya gelmelerinin zemini sağlam ve bilinçli bir şekilde hazırlanmalıdır. Gençlerle yaşlıları biraraya getirecek bu düzenlemeler kapsamında, gençlerin belli aralıklarla kızlı erkekli yaşılları ziyaret etmeleri sağlanabilir. Bu ziyaretler dahilinde, gençler yaşlılarla sohbet edebilir; yaşlılarla hal-hatır sormak şeklinde ilgilenebilir; yaşlılarla birlikte, özellikle de yalnızlık sorunu olan yaşlılarla, yürüyüş yapma, parka gitme, vb türden faaliyetler yapabilirler.

Ayrıca, bu türden faaliyetleri genişletebilmek için yerel yönetimler, amaca ve ölçütlere uygun sivil toplum kuruluşlarını da çalışmalara dahil etmenin yol ve yöntemlerini geliştirmelidir. Böylece, çalışmaların etki ve erişim alanı daha da kapsamlı bir hale getirilebilecektir. Tüm bu faaliyetler neticesinde, gençlerle yaşlılar arasında, hayatın doğal akışı içinde sağlam bir köprünün kurulabilmesi mümkün olacaktır.

Çok çeşitli biçimleriyle "Medya"nun çok sayıda insana kolayca ulaştığı ve çok yaygın etki alanı olduğu düşünüldüğünde, medyanın bu makalede ele alınan sorunlar açısından da çok önemli bir faktör olduğu görülmektedir. Bu önemli faktör, bir yandan kuşaklararası mesafe ve çatışmaları güçlendirerek olumsuz etki yapabilmektedir. Fakat medya, aynı zamanda, bu mesafe ve çatışmaların giderilmesi için de çok etkili bir çözüm aracı potansiyeli taşımaktadır. Bu nedenle, medyanın nasıl kullanıldığı çok büyük önem taşımaktadır.

Burada, hem medyanın ele alınan sorunlara yol açma biçimleri ele alınacaktır, hem de bu sorunların çözümlenmesinde nasıl aktif bir rol oynayabileceği, nasıl yararlı bir araç olarak kullanılabileceği ortaya koyulacaktır. 
Öncelikle, medyanın, yaşlılarla ilgili olarak yukarıda tartışılan önyargıların oluşturulmasına katkı sağlayan olumsuz etkisi görülmelidir. Televizyon, radyo, gazeteler gibi çok yaygın etkiye sahip araçlarda, yaşlıların belli bazı kalıp tiplemeler şeklinde yansıtılması çok önemli bir sorun oluşturmaktadır. Yaşlılarla ilgili yukarıda tartışılan önyargılar çerçevesinde çizilen yaşlı figürleri kurgusal olarak oluşturulmakta ve tekrar tekrar sunulmaları yoluyla yaygınlaştırılmakta ve kalıcılaştırılmaktadır. Medyada yaşlıların nasıl ve ne oranda yansıtıldığı konusunda Kuroğlu ve Salman'ın da belirttikleri gibi:

Toplumların önemli bir kesimini meydana getiren bu grup, dünyada ve Türkiye'de medya tarafından ya görmezden gelinmekte ya da gerçek hayatta olduğundan çok daha farklı ve uzak bir şekilde temsil edilmektedir. Bir başka deyişle, yaşlıların medyada yeterince temsil edilmediği, ya da eksik ve/veya yanlış temsil edildiği gözlemlenmektedir" (Kuroğlu ve Salman, 2017, s.1).

Bu türden farklı temsillerde, yaşlılar kimi kez karikatürize edilerek ya da komikleştirilerek sunulabilmektedir. Örneğin, herhangi bir bireyin hayatında olabilecek sıradan faaliyet ve durumlar (ilişkiler, cinsellik, evlilik, eğlenmek, sosyal faaliyetler, vb), yaşlıların hayatında olduğunda komikleştirilerek sunulabilmektedir.

Oysa, medyada yaşlılar, kalıpyargılardan kurtulmuş, saygın bireyler olarak tanımlanmalıdır. Özel yaşam, sosyal yaşam, başarılı ya da başarısız olma, vb her türlü yetişkin insan tecrübesi açısından yaşlılar, saygın yetişkinler olarak sunulmalılar. Herhangi bir yetişkin insan tecrübesi ile ilgili bir tanımlama, sözkonusu birey yaşlı olduğunda, farklı bir üsluba büründürülmemelidir. Yaşlılık tanımının da gerçekçi yapılması, sıradan insana hitap eden gerçekçi tanımlar sunulması büyük önem taşımaktadır.

Bununla bağlantılı olarak, yaşlıları, mazlum, hasta, engelli olarak tasavvur etme eğilimine son verecek bir algı oluşturmak, yaşlıları bu farkındalık içinde temsil etmek çok önemlidir. Bu özelliklerin yaşlıya özgü değil, tüm yaş gruplarından kişilerde görülebilecek dezavantajlar olduğu gerçeği de vurgulanmalıdır. Bunun sonucu olarak da, yaşlılara karşı takınılacak tutumda, acıyarak yaklaşmak yerine, sorumluluk alarak ortaya koyulacak pozitif ayrımcılık fikri gündeme getirilmelidir. Yaşlıları temsil ederken; yaşlılar acınacak ya da gülünç bulunacak, adeta çocuklaştırılarak yaklaşılacak kişiler olarak değil de tüm artıları ve eksileri ile saygın yetişkin bireyler olarak yansıtılmalıdır. 
Yine medyada da yerini alan bir başka yanlış temsil biçimi ise, daha genç kuşaklar ile yaşlılar arasındaki ilişkilerle ilgili olabilmektedir. Temsilleri sunulan bu sorunlu ilişki biçiminde, yaşlılar adeta çocuklaştırılmaktadır. Gençlerin, yaşlıların ebeveynleriymişler gibi davranması, yaşlıları kontrol etmeye çalışması, onlar adına kararlar vermeye kalkması gibi durumlar, hem bu yaklaşımı olağanlaştırılmakta hem de, sonuç olarak, konu edilen yaşlı karakterleri gülünçleştirilmektedir.

Örneğin, "cömert ve tonton" sevimli yaşlılar ya da torunlarının sürekli olarak kendisinden bir şekilde harçlık almaya çalıştığ 1 "cimri" büyükannebüyükbaba tiplemesi, kalıplaşmış pekçok yaşlı-genç ilişkisi türüne bir örnek olarak gösterilebilir. Bu örnek, yukarıda öğrenci cevaplarını tartışırken, ikinci grup öğrencilerinden birinin, yaşlıların "sanki cebinde akrep var gibi cimrileşmeleri" ni sevmediğini belirtmesini hatırlatmaktadır ve bu klişelerin gerçek yaşamdaki beklentilerde kendini yansıttığını ortaya koymaktadır. Yaşl1lar ile gençler arasındaki ilişkinin temsili, bu iki grubun mensuplarını, karşılıklı saygı çerçevesinde bir araya gelmiş iki yetişkin olarak sunmalıdır.

Medyada olumsuz olarak göze çarpan bir diğer konu ise, radyo, televizyon, gazeteler gibi çeşitli medya araçlarında sağlık konusunda özellikle yaşlılara yönelik bilgilendirici programların neredeyse yok denecek kadar az olmasıdır. Genel olarak sağlıkla ilgili pekçok program olmasına rağmen, özellikle yaşlılıkla ilişkili sağlık meselelerine odaklanan haber ve programlar bulunmamaktadır. Oysa yaşlıların, bu gibi sunumlara çok ihtiyaçları olduğu açıktır. Bu konularda, mutlaka bir uzman tarafından ya da uzman denetiminde hazırlanacak yaşlılara yönelik çok yönlü programlar, haberler yayımlanmalıdır. Bu türden imkanların, onların hayatlarına hem çok katkıda bulunacağ 1 hem de kendilerini toplumda önemli ve değerli bireyler olarak hissetmelerini sağlayacağı muhakkaktır.

Sağlıkla ilgili haber ve programların dışında da, yaşlı bireylerin ihtiyaç ve ilgileri doğrultusunda, özellikle kendilerine yönelik haber ve programların yapılması ve yayımlanması çok önemli bir boşluğu dolduracaktır. Uzman bilgisi ve denetimi çerçevesinde gerçekleştirilecek spor, sosyal yaşam, zamanını verimli geçirme, faaliyetler, kültür-sanat, vb konularda özellikle yaşlı bireylere yönelik bilgilendirici programların neredeyse yok denecek kadar az olduğu görülmektedir. Bu eksiklik, hızla ve nitelikli olarak doldurulmalıdır. 
Sosyal medya ise, günümüzde etkisi giderek büyümekte ve yayginlaşmakta olan bir alan olarak, konumuz kapsamında da önemle ele alınması gereken bir alandır. Öncelikle vurgulanması gereken nokta, bu alanın özellikle gençlerin çok aktif olarak var olduğu bir alan olduğudur. Bu nedenle de, sosyal medya, gençlerin ve yaşlıların dünyalarının büyük bir çoğunlukla bir arada bulunmadığı ve sunulmadığı bir zemin olarak ortaya çımaktadır. Sonuç olarak da, bu zemin, bu iki grup arasındaki mesafenin ve karşllıklı yabancılaşmanın güçlendiği bir ortam olarak görülebilir.

$\mathrm{Bu}$ alan, genellikle fikirlerin çok rahatça dile getirilebildiği, hatta bazen isimsiz olarak ya da takma adlarla fikirlerin sunulabildiği bir zemin olduğundan, genellikle tüm kontrol ve sınırlamalar devre dışı kalabilmektedir. Bu nedenle de bu alan, kontrolsüzce eleştirel, sert, uyumsuz, hatta saldırgan olabilmeye de imkan tanımaktadır. Bu açıdan da, bu zeminde, kuşaklararası uyumsuzluğun da en sert ve kontrolsüz biçimlerde tanımlanabildiği görülebilmektedir. Bu ortamda, yüzyüze görüşmelerde ortaya koyulamayacak ve kabul edilemez tavirlar serbestçe kendine yer bulabilmektedir. (Öte yandan, şu da belirtilmelidir ki, sosyal medyanın yukarıda değinilen özelliklerinin yol açtı̆̆1 sorunlar, aslında sadece yaşlılara karşı tutumun olumsuz olabilmesi ile sınırlı değildir. Bunun dışında pekçok başka konuda da çözüme ihtiyaç duyan meseleler içermektedir.)

Bu nedenle de, fikirlerin çok hızla çok büyük kitlelere ulaşabildiği ve etkisinin yaygınlaşabildiği bu ortamın sağlıklı, uygarca, yapıcı bir iletişim ortamına dönüştürülebilmesi çok büyük bir önem taşımaktadır. Özellikle, okullarda, gençlerin çok aktif ve yoğun olarak ilişki içinde oldukları bu alanla ilgili bilinçlendirici çalışmalar yapılması çok önemli bir başlangıç noktası olacaktır. Dijital ortamın ve sosyal medyanın sağlıkl, verimli ve yapıcı amaçlarla kullanımına yönelik çok ciddi, planlı ve disiplinli çalışmaların yapılması, eğitim kurumları için bir zorunluluktur. Yaşlı insanların, eğitim kurumları çerçevesinde gençlerle daha fazla biraraya getirilmesine yönelik olarak makalenin daha önceki bölümlerinde yapılan öneriler de bir açıdan bu amaca hizmet edecektir. Ayrıca, yaşlı insanların da sosyal medyaya daha fazla dahil edilebilmesine yönelik çaba ve çalışmalar da hem bu meseleye önemli bir katkı olacaktır, hem de yaşlı bireylerin yaşamlarının daha fazla sosyal imkanla buluşturulması anlamına gelecektir.

Çok yaygın ve olumlu etkisi olabilecek bir diğer faaliyet ise, medya organlarında konuya ilişkin doğru, bilgilendirici ve yapıcı yönde harekete geçirici 
kamu spotlarının yayımlanması olacaktır. Bu yayınlarda, gençlerle yaşlı bireyler arasında saygıya dayanan ilişkiler yansıtılmalıdır. Yaşlı bireylerin ihtiyaçların karşılanması için sorumluluk duygusuyla ve saygıyla harekete geçilmesine katkıda bulunacak sunumlar yapılmalıdır. İzleyicilerde, okurlarda yaşlılık ve yaşlılarla ilgili hassasiyet, bilinç ve sorumluluk uyandıracak içerikler oluşturulmalıdır. Bu kamu spotlarında, yaşlılarla gençlerin aktif ve uyumlu beraberliğini örnekleyen temsiller sunulmalıdır. Yaşlıları korunmaya ya da desteklenmeye muhtaç aciz kişiler gibi göstermeden onlara saygiyla destek olunduğu sahneler bilinçle üretilmeli ve izleyicilerle, okurlarla buluşturulmalıdır. Böylece, yaşlılarla toplumun geri kalanı arasında sağlıklı bir ilişki tesis edilebilmesine yönelik çok işlevsel çalışmalar ortaya çıkacaktır.

\section{Sonuç}

Bu çalışmanın başında ayrıntısıyla verilen ve bir örneklem grubunu oluşturan gençlerin yaşlılara bakışındaki olumsuzluğu gösteren cevaplar, yukarıda da tartışıldığı üzere, çok büyük bir ciddiyetle ele alınmalıdır. Çünkü bu cevapların çok büyük bir çoğunluğu, sadece belli bazı eleştirileri içeren sade cümlelerden oluşmamaktadır. Yaşlılarla ilgili olarak eleştiri ortaya koymanın çok ötesine geçen, çok sert ve açıkça dişlayıcı bir tutumun bazı gençler arasinda yayginlaşmakta olduğu görülmektedir. Bu nedenle de, bu cevaplar, bir tür uyarı gibi, bir tür acil durum ifadesi gibi etki yaratmalıdır. Bireylerarası ilişkilerin ve toplumun sağlıklı bir şekilde işleyebilmesi; bireysel ve toplumsal hoşnutluğun ve mutluluğun var olabilmesi için; bu cevaplarda varlığ 1 hissedilen dışlayıcı, yabancılaşan, bağları koparan tutumun analiz edilerek çözümlenmesi çok acil bir sorun olarak ortaya çıkmaktadır.

Bu amaca yönelik olarak da, makalenin tartışma ve öneriler başlığı altında sunulan türden çözüm önerileri sadece bir başlangıç çabası olarak kabul edilebilir. Bu tanımlama ve önerilerden yola çıkılarak üretilebilecek pekçok başka yeni farklı önerilerin ciddiyetle ele alınması ve uygulanma imkanlarının yaratılması gerekmektedir. Diğer bir değişle, farkına varılan bu sorunların çözümüne ilişkin eyleme geçme zorunluluğu ortadadır. Yani, makalenin başında verilen Goethe sözünün ifade ettiği gibi: "Bilmek yetmez, bilgimizi kullanmalıyı da; istemek yetmez, yapmalıyız da". Sağliklı genç ve yaşlı bireylerin, sağlıklı toplumsal ilişkilerin, sağlıklı ve verimli bir sosyo-kültürel, ekonomik, siyasal düzenin var olabilmesi, bunları yapabilmekle mümkün olabilecektir. 


\title{
EXTENDED ABSTRACT
}

\section{The Critical Approach of Young People to the Elder- ly within the Context of Intergenerational Conflict: A Sample Group, Problems and Suggestions for Solutions}

\author{
* \\ Tümer Ulus \\ İstanbul Üniversitesi Cerrahpaşa
}

It is a fact that since the beginning of history, there have been communicational problems and intergenerational conflict between young and elderly people. This has caused both personal and social problems, weakening the potential productivity not only in the personal lives of young and elderly individuals but also in the workings of society surrounding them. It has created distance and alienation between these two groups, who can and should benefit from one another. This article, by working on a sample group, aims to analyse how young people see elderly people (leaving the other side of the issue, namely the subject of how elderly people see young people to another article which is currently being prepared by the writer of this article). This article tries to understand from which aspects young people criticize elderly people, to discuss the problems and to suggest solutions.

The members of the sample group were especially selected from among the university students studying at the departments of Gerontology, Social Work, and Physical Therapy and Rehabilitation. They are students studying in their first, second, fourth and eighth semesters. Accordingly, they had already taken compulsory and/or elective courses on aging and old age and were expected to have knowledge on the subject. (They have taken, among others, the following courses taught by the writer of this article: "Sociological aging", "Psychological aging", "Biological aging", "Free time activities in the old age", "Elderly care", "Healthy aging", "Anthropology", "Intergenerational relations", "Education for the elderly", and "Elderly care models".) Through the structured question-answer method, these sample group students were asked a question about their negative 
views on elderly people: In the classroom, without any prior preparation, students were asked to write down two points that they are most critical of with regard to the elderly people. They were asked not to write any personal information that would make their identities known (their names, student IDs, etc) on the answer sheets. The article first presents data on the question asked and the answers received. Then, it discusses the observed problems in detail and offers suggestions for the solution.

In the "data analyses" section, the answers given by the students have been divided into three different categories depending on their approach and attitude to the elderly, and then the analyses and discussions have been built upon that framework. Those three categories can be summarized as follows: The answers included in the First Group show that the relations between these students and elderly people are very weak. The students state in their answers that there are considerable insufficincies in the communication between the young and the elderly, that the young and the elderly do not really know each other and they share very little. The answers which are collected under the Secong Group emphasize, first of all, the same "intergenerational conflict" problem that is observed in the answers of the First Group. Yet, in addition to that, the answers included in the Second Group show a much more negative attitude to the elderly, which goes beyond the intergenerational conflict problem. They present a very rigid boundary between those two different generations. Even the language that they employ as they state and emphasize the lack of communication and understanding between the young and the elderly, may at some points be really harsh and show an exclusionary, discriminatory, disrespectful and even cruel attitude. This attitude ultimately deepens the gap between the young and the elderly. The very few answers which were found out to constitute a Third Group, on the other hand, present a much more positive approach compared to the first and second groups. The students who give these Third Group answers tend to show understanding with regard to the differences and the lack of communication between the young and the elderly and are willing to emphatize with the elderly, to learn more about them, and to improve the weak communication and relations between the two generations. However, the number of those included in the Third Group are very few.

Having defined and discussed the answers received from the students, the article presents suggestions as to how those problems can be solved: As a 
starting point, the importance of showing an inclusive attitude not only with regard to the personal relationships but also with regard to the wider sociocultural context was emphasized and discussed in detail. The necessity of revising the exclusinory stereotypical definitions of the old age and of the elderly has been particularly and strongly put under focus. Within this framework, firstly, the "family environment" where the identities and values of the young members of society are formed and shaped was discussed as a crucial context where the attitude of the child to the elderly takes its first and most important shape. Then the "educational institutions" were analysed and discussed with regard to their potentialities to erase the intergenerational gaps and to improve and strengthen intergenerational relations with detailed examples. The "media" was also discussed in detail with regard to its impact not only as a tool which can create exclusionary stereotypical definitions of the elderly members of society but also as a potential channel through which these established stereotypes could be revisioned, criticized and invalidated. Also, the potential constributions that are and can further be made by both governmental and non-governmental bodies in strengthening the bonds between the young and the elderly in the active realm of social life are discussed in detail. The article presents a detailed list of suggestions regarding the actions that can be performed by or with the help of ministries (the Ministry of Family, Labour and social services in particular), municipalities, elderly care homes, educational institutions, among others, as well as by the more personal social environments. Having discussed the problems and potential solutions in detail, the article claims to be a starting point in this issue which, no doubt, is open to further development.

\section{Kaynakça / References}

Buz, S. (2015). Yaşlı bireylere yönelik yaş ayrımallı̆̆. Elektronik Sosyal Bilimler Dergisi, 14(53), 268-278.

Canatan, A. (2008). Toplumsal değerler ve yaşlılar. Yaşlı Sorunlan Araştırma Dergisi, 1, $62-71$.

Çayır, K. (2011). Yaşçlık-yaşa dayalı ayrımclık. İstanbul Bilgi Üniversitesi Sosyoloji ve Eğitim Çalı̧̧malan Birimi (seçbir) http://secbir.org/images/haber/2011/02/yass1.pdf adresinden erişilmiştir.

Çiftçi, O. (1991). Çocuğun sosyalleşmesinde ailenin rolü. Aile ve Toplum, 1(2), 19-22. 
Ferchoff, W. (2011). Jugend und Jugendkulturen im 21. Jahrhundert: Lebensformen und Lebensstile. Wiesbaden: VS Verlag.

İstatistiklerle Yaşlılar (2016). Türkiye İstatistik Kurumu, http://www.tuik.gov.tr/PreHaberBultenleri.do?id=24644 adresinden erişilmiştir.

Kuroğlu, H. ve Salman, S. (2017). Medyada yaşlılık ve Türk sinemasında yaşlılık temsili. Abant Kültürel Araştırmalar Dergisi (AKAR), 2(3), 1-23.

Levent, L. (2015). Aile: Diyanet. 5-9

Lofti, A., Kabiri, S., ve Ghasemlou, H. (2013). Değerler değişimi ve kuşaklararası çatışma: İran Khoy Kenti örneği. Eskişehir Osmangazi Üniversitesi Sosyal Bilimler Dergisi, 14(2). 93-113.

Roux, P., Gobet, P., Clemence, A., ve Höpflinger, F. (1996). Generationen beziehungen und altersbilder ergebnisse einer empirischen studie. Nationales Forschungs programm 32 Alter/Vieelesse Lausanne/Zurich, 14-18.

Power, B. (1992). Attitudes of young people to ageing and the elderly. National Council for the Elderly Report no:16.

Sinan Ö. ve Bilgili N. (2019). Yaşlılıkla ilgili yaygın inanç, tutumlar ve sağlık hizmetlerine yansıması. HEAD Koç Üniversitesi Hemşirelik Eğitim ve Araştırma Dergisi, 16(3), 246-251.

Ucun, Y., Mersin, S., ve Öksüz, E. (2015). Gençlerin Yaşlı Bireylere Karşı Tutumu. Uluslararası Sosyal Araştırmalar Dergisi, 8(37), 143-149

Yıldırım, F. (2015). Çocukların dünyasına yaşlıları dahil etmek: Okul temelli kuşaklararası dayanışma modelleri. TSA, 1, 275-296

\section{Kaynakça Bilgisi / Citation Information}

Ulus, T. (2020). Kuşaklararası çatışma bağlamında gençlerin yaşlılara eleştirel bakışı: Bir örneklem, sorunlar ve çözüm önerileri. OPUSUluslararası Toplum Araştırmaları Dergisi, 16(28), 1154-1182. DOI: 10.26466/opus.677142 